\title{
HIPPOLYTUS, THE LAMIA, AND THE EUNUCH: \\ CELIBACY AND NARRATIVE STRATEGY IN PHILOSTRATUS' LIFE OF APOLLONIUS
}

\author{
GRAEME MILES
}

\section{INTRODUCTION: NARRATIVE CHALLENGE AND RESPONSE}

$\mathrm{P}$

HILOSTRATUS' LIFE OF APOLLONIUS OF TYANA, the novelistic biography of a celibate ascetic, holy man, and Pythagorean philosopher, is a work full of echoes of classical Greek literature. ${ }^{1}$ This deeply learned, and often deeply puzzling, text has received renewed attention and appreciation over the last few decades. ${ }^{2}$ Once regarded as a historical work of dubious value, it has become increasingly clear that it knowingly and inextricably blends history and fiction, and expects astute readers, willing to tease out its interweaving of allusions and actively to create its meaning. ${ }^{3}$ The protagonist of the $V A$ provides Philostratus with a number of rhetorical and narrative challenges, not the least of them being his very character as a Pythagorean. ${ }^{4}$ This Pythagoreanism, it should be added, is a very specific selection out of the available "Pythagorean" traditions: ${ }^{5}$ the text's depiction of Apollonius' philosophy does not refer to mathematical or musical theory, but makes much of the school's teachings on vegetarianism, sexual restraint, and reincarnation. For all that celibacy was well-established in Pythagoreanism, it was still far from a mainstream value. So Philostratus' problem, in this instance, lay in presenting this in acceptable and even praiseworthy terms, in rendering his celibate ascetic heroic.

To this end he makes use of a series of subnarratives reworking the myth of Hippolytus; several other episodes involving supernatural, sexual predators (the lamia, an empousa, and the ghosts of a soldier and a satyr); and an important contrast between Apollonius' rejection of sexuality and the false self-control

1. I use hereafter the usual abbreviation VA (for Vita Apollonii) though with the equally usual disclaimer that this should not suggest a narrow generic classification as purely a biography.

2. See esp. G. Anderson 1986; 1993; 1994; Billault 1991; 2000; Koskenniemi 1991; 1998; Bowie 1994; Flinterman 1995; Francis 1995; 1998; Elsner 1997; Jones 2001; Schirren 2005; the papers in Bowie and Elsner 2009 and Demoen and Praet 2009; Hägg 2012, 318-40; Abraham 2014. Still fundamental: Meyer 1917; Jones 1974; Bowie 1975. Translations: into English, Conybeare 1912; Jones 2005; into German, Mumprecht 1983; into French, Grimal 1958.

3. On the VA's expectations of readers and its hermeneutic prompts, see Miles 2009. On particular strands in its web of allusions: regarding the use of Euripides' Bacchae, see Praet et al. 2014; on the Odyssey, Van Dijk 2009.

4. On Apollonius' Pythagoreanism: Flinterman 1995; 2009.

5. Burkert 1972; O’Meara 1990; Zhmud 2012.

Classical Philology 112 (2017): 200-218

[C 2017 by The University of Chicago. All rights reserved] 0009-837X/17/11202-0005\$10.00 
of a Babylonian eunuch. Graham Anderson has suggested that the inclusion of the Hippolytus stories and that of the lamia is a way of bringing into the text romance elements that could not appropriately be applied to Apollonius himself. ${ }^{6}$ This is a valid point, but there is more here than just an attempt to entertain readers with some variation from stories of the protagonist's holiness, as I hope to demonstrate in the following discussion. Futhermore, these episodes differ from the novel in that an entirely negative view of erōs is presented. This, as Ewen Bowie observes, is one of the most important differences between the $V A$ and the novel. ${ }^{7}$ The $V A$ 's use of the myth of Hippolytus is just as selective as its treatment of Pythagoreanism: both the points of similarity and the differences between Apollonius and Hippolytus are meaningful. In Apollonius' encounter with a eunuch, the protagonist's character is once more illuminated by further similarities and differences. Finally, the supernatural sexual predators whom Apollonius is able to defeat allow a concrete demonstration of the power of his own restraint.

\section{HipPolytus AND the ReJection OF SEXUALity}

Before examining the $V A$ 's use of the myth of Hippolytus, it will be necessary to sketch some background of the uses to which this myth was put in Greek culture of the Roman era. Naturally, a discussion of Philostratus is not the place for a complete overview of the reception and reworking of this myth, but some examples can reveal both that the myth, especially as dramatized in Euripides' Hippolytus the Wreathbearer ${ }^{8}$ was well-known, and that it was evidently put to varied uses, and sometimes rather suprising ones. That the play is one of the "selected" plays that come down to us with scholia rather than one of the "alphabetical" plays may itself indicate a higher profile in the centuries after Euripides. ${ }^{9}$ The numerous references to the play in the Greek novels, as well as those in Philostratus, demonstrate that it retained a prominent position in the cultural imagination.

Visual representations indicate a lively interest in the myth in the Roman era; Hippolytean themes were popular on Roman sarcophagi, surviving in around forty extant examples. These sarcophagi divide into two broad types: (1) those depicting Phaedra tormented by passion and Hippolytus on a boar hunt, and (2) those depicting Theseus receiving news of Hippolytus' death. ${ }^{10}$

6. G. Anderson 1986, 230. For a more extensive discussion of the use of novelistic elements in the $V A$ and Heroicus, see Bowie 1994. In these episodes, as in much of the $V A$, Schirren sees irony and comedy, e.g., 2005, 221-22 on the lamia. The supposed resemblances between Philostratus' lamia story and New Comedy do not seem to me sufficiently compelling to support an outright comic reading.

7. Bowie 1986, 190-93.

8. It is well-known that this surviving Hippolytus of Euripides was his second attempt at staging this myth; despite the existence of the first version, it appears that the second became by far better known. For the scanty fragments of Hippolytus Veiled, see Nauck and Snell 1964, 491-96. Sophocles' Phaedra is just as shadowy as Euripides' first attempt: see Radt 1977, 475-81. On the Latin side, the major telling is Seneca's Phaedra/Hippolytus. Though we should not assume that Philostratus was unfamiliar with Latin literature, Seneca's play does not bear on the present discussion.

9. For the scholia to Hippolytus, see Schwartz 1891, 1-136; on those concerned with the play's imagery and symbolism, see Hunter 2009.

10. Zanker and Ewald 2012, 344-48. On visual representations of Hippolytus more broadly, see the articles in the LIMC by Linant de Bellefonds (1990, 5.1.445-64 and 5.2.316-27) and of Phaedra (1994, 7.1.356-59 and 7.2.314-16) 
In both cases the deceased is likened to the departing or dying Hippolytus, and the grieving relatives to Phaedra or Theseus. As Paul Zanker and Björn C. Ewald observe, these uses of the myth require observers to abstract from the narrative context, seeing in Phaedra's unhappy love "an allegory for the love and pain of parting." 11 What is most striking about these visual adoptions of the story of Hippolytus, Phaedra, and Theseus to the context of mourning is the selectivity that is expected of viewers in their reception of the image. Viewers are evidently expected to put to one side the aspects of the story that are not appropriate to the new context, even though those details to be suppressed include much that is most important to the myth itself. In Philostratus we shall see a somewhat similar selectivity, though a verbal adaptation of the story to new circumstances has the advantage of guiding its audience more directly toward the aspects of the story deemed relevant.

The works of the Corpus Philostrateum have often, and rightly, been placed in the context of the "fringe" of the ancient novel: not quite full members of the group but clearly sharing some similarities with them. The uses of the Hippolytus myth in several novels shed further light on Philostratus, both for the evident care with which they too deploy this mythic paradigm, and for the differences that arise in adopting Hippolytus for the depiction of chastity prior to an eventual marriage, as opposed to the lifelong celibacy of Apollonius. ${ }^{12}$ In the first of the surviving novels, Chariton's Callirhoe, the hero Chaereas is likened to the sculptures of several historical and mythic figures: Achilles, Nireus, Alcibiades, and Hippolytus (1.3). Beyond conveying the hero's beauty, this opening allusion is clearly part of a broader Hippolytean characterization: in addition to the sophrosyne that he shares with other novelistic heroes, it is Chaereas' offense against Aphrodite (kicking his pregnant wife) that is the main driver of the novel's plot. ${ }^{13}$ Similarly, Habrocomes, in Xenophon of Ephesus' Ephesiaca, begins the novel as a hunter with a disdain for sexuality, who then incurs divine punishment, though by Erōs rather than Aphrodite. Unlike his classical predecessor, Habrocomes is able to learn the error of his ways, bringing the paradigmatic relationship with Hippolytus to an end. ${ }^{14}$

A further Hippolytean reference appears in the tantalizing fragments of a lost novel assembled by Klaus Alpers. ${ }^{15}$ In fragment 21 an unknown speaker likens an unknown listener to Hippolytus, saying: "But you, just like Hippolytus from Troizen, raise your eyebrows and bite your lip and bow your head, and you run past us silently as if past a hero's shrine."16 Stripped of its context it is difficult to say much more, but it is clear that once again the point of comparison was the disdain of Hippolytus, and very likely his contempt for sexuality. As Alpers observes, the passage is imitated by Aelian in Letter 12:17 "And from the

11. Zanker and Ewald 2012, 48.

12. On myth in the novels, see Bremmer 2013; De Temmerman and Demoen 2011; Cueva 2004.

13. Hippolytus as analogue to Chariton's Chaereas: Scourfield 2010; Hunter 1997, 1079; Cueva 2004, $24-25$.

14. De Temmerman and Demoen 2011, 4.

15. Alpers 1996.

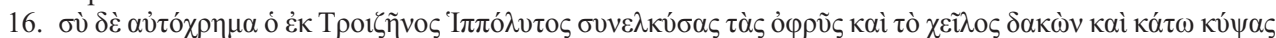



17. Alpers 1996, 48 
time when you began to hunt you have become just like Hippolytus. But see to it that Aphrodite does not become enraged with you for your contempt."18 Alpers' fragmentary novel, the letter of Aelian, Xenophon's Ephesiaca, and Chariton's Calliorhoe all, in short, employ Hippolytus as an exemplar of the beautiful youth disdainful of sexuality.

Heliodorus also includes in the Aethiopica an incident evocative of Hippolytus. ${ }^{19}$ Early in the novel the protagonists, Theagenes and Charicleia, are told the adventures of a fellow Greek, Cnemon, whom they have met in Egypt. The story that he tells them, of his lusty stepmother and the disastrous results of his chastity, is evidently very similar to the story of Hippolytus (Heliod. 1.9.11.18.1). While the nature of the story is quite clear both to the internal audience (Theagenes and Charicleia) and to the external audience (the readers of the novel), for the characters involved the question appears to be: what story is this?

It is clear from early in his tale that Cnemon sees the situation as a repeat of Hippolytus. Demainete, his stepmother, however, seems unsure whose role is

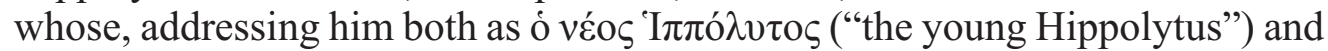

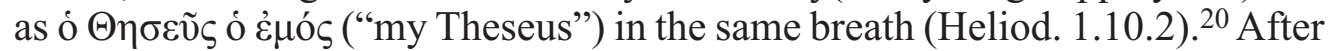
Cnemon has rejected her advances, however, she describes her relationship to him in different terms when accusing him to his father, describing him now as

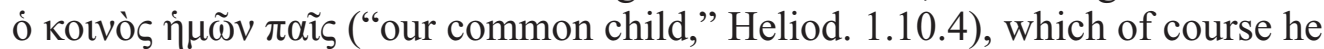
is not. This leads into what will appear to Cnemon's father to be an Oedipal situation, but one in which Cnemon believes himself to be defending his father by discovering his stepmother's lover. Upon bursting into the bedroom with sword in hand, however, he discovers that he is in a different story, appearing to be a knowing Oedipus to his father while realizing himself to be a framed Hippolytus. In addition, the elaborate mistaken identities and Cnemon's name might give readers the impression that these are characters in a New Comedy. ${ }^{21}$ Demainete, however, has forgotten that a Phaedra cannot end happily and that she never gets her Hippolytus, and so falls for Thisbe's trick and ends with the suicide required by her role (Heliod. 1.17.5).

The mythological parallels that Heliodorus draws in this tale are deployed differently than those of Philostratus in the $V A$, being intertwined with the shifts in the plot in a way that those of Philostratus are not. Though both the internal

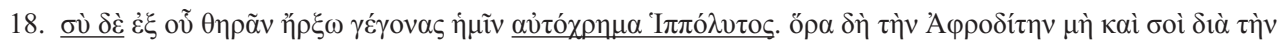

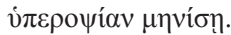

19. For analysis of some of the many points of contact between the $V A$ and Heliodorus, see Morgan 2009. On Cnemon's story, see Morgan 1989, esp. his comments on the use of Hippolytus (p. 112). See also the discussion of the use of Hippolytus in the Aethiopica by Cueva (2004, 83-96). Achilles Tatius (1.3) alludes only briefly to the story of Phaedra and Hippolytus in the tirade against love and women by Clinias, a friend of the hero.

20. Textual corruption has been suspected at this point and Rattenbury and Lumb (1994) obelize the phrase, and consider that if Heliodorus wrote this, he was guilty of "une faute de goût" in having Demainete liken her situation to that of Phaedra. The codices are, however, unanimous in the reading, and whether these words constitute a fault of taste is itself a matter of taste. Given the shifting and uncertain roles of the characters in Cnemon's story, it seems best to let Demainete's extraordinary line stand. Seneca's Phaedra, incidentally, also compares Hippolytus' appearance to his father's when she attempts to seduce him: 646-71, esp. 658-60: "in te magis refulget incomptus decor; / est genitor in te totus et torvae tamen / pars aliqua matris miscet ex aequo decus: / in ore Graio Scythicus apparet rigor."

21. A character named Cnemon also appears in Menander's Dyskolos. 
and external audiences know from quite early on what type of story Cnemon's tale will turn out to be, for the characters the plot itself moves by the shifting of one mythic parallel to another. ${ }^{22}$ Because of the certainty with which even the first-time reader recognizes this as a Hippolytus story, the mythic paradigms that the characters introduce in order to interpret their situation present themselves as a sort of dramatic irony through allusion. In the $V A$, on the other hand, it is not this shifting of intertext that is produced, but a sense of tragic narrative recurring (mutatis mutandis) in the present. ${ }^{23}$

Like the Hippolytus stories in the VA, that in Heliodorus is an inserted narrative told by a secondary character, Cnemon (Heliod. 1.9.1-1.18.1). ${ }^{24}$ The Hippolytus stories in both texts develop a concern of the main narrative: the responses of the protagonists to unwanted sexual advances. In Heliodorus, this connects with the dominant theme of the preservation of chastity by the hero and heroine, a drama played out in the scenes with the brigand Thyamis and the evil queen Arsake (Heliod. 1.18-1.33, 7.9-8.11). In the $V A$ the notion of sexual purity is taken much further in the complete, lifelong celibacy of Apollonius, but the Hippolytean legend can still be introduced as a supporting subplot. The inclusion of these stories and Apollonius' approval of their protagonists take on an even greater importance since there are so few threats to Apollonius' own celibacy in the main narrative.

These numerous references to Hippolytus in the novels treat the myth quite differently than the sarcophagi. While the latter are concerned primarily with the emotions evoked, in particular the sufferings of love and separation, the novels employ Hippolytus as a paradigm of a beautiful youth who is disdainful of sexuality. Xenophon of Ephesus and Chariton both include the motif of offended divinity, and Heliodorus employs Cnemon's Hippolytean tale as a contrast to the chaste love of Theagenes and Charicleia. While the uses of Hippolytus in the $V A$ share some common ground with those in the novels, their effects are, as will emerge, quite distinct.

Apollonius' renunciation of sex and marriage comes early in the $V A$ while he is still a youth (1.13). While Pythagoras, the narrating voice states, had said that a man ought only to have sex with his own wife, the young Apollonius goes further, believing that Pythagoras' advice is only for other people and that he himself should abstain entirely. The teachings ascribed to Pythagoras in fact varied on this point between the more relaxed advice quoted by Philostratus and the complete celibacy that is attributed to Apollonius here. ${ }^{25}$ The attribution of the less extreme position to Pythagoras is typical of Philostratus' method. By choosing a milder Pythagoras, it becomes possible to depict Apol-

\footnotetext{
22. Philostratus' intertextual practice in the Heroicus, by contrast with the $V A$, is closer to that of Heliodorus in Cnemon's story. See the analysis by Maclean (2004) of the intertextual shifts used to define the conversion of the Phoenician from scepticism to belief, though I cannot agree that readers are guided to model their own conversion on his.

23. For discussion of other aspects of Heliodorus' interpretive play, see Bartsch 1989 and Winkler 1982, among others. On characterization in the novels, see now De Temmerman 2014. For comparison of the Hippolytus myth with that of the Syrian Combabus, see Elsner 2001, 148-49.

24. On the use of Hippolytus as analogue to Theagenes in the Aethiopica, see also Cueva 2004, 83-90, 133 n. 26.

25. Burkert 1972, 178 n. 94.
} 
lonius going beyond a famous predecessor, as he does throughout the text. ${ }^{26}$ It is important too that Apollonius' celibacy is a special rule for him alone, not, as in the roughly contemporary Acts of Thomas, a rule that everyone should follow (ATh 12). ${ }^{27}$ The extreme demands of the Acts of Thomas are based in a disgust with the body and the world that is far beyond the relatively mild asceticism of the Life of Apollonius. ${ }^{28}$

Philostratus dismisses the accounts of some who claim that the sage was mastered by lust and that he even went into self-imposed exile among the Scythians for a year because of an "erotic error" or "guilty passion" ( $\delta 1 \alpha \mu \alpha \rho \tau i ́ \alpha$

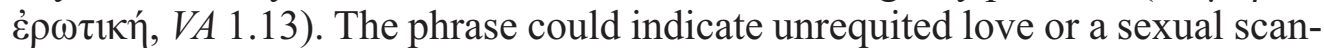
dal, ${ }^{29}$ but in either case Philostratus' denial of any erotic rumor is clear. From the Lives of the Sophists, and from Lucian's Alexander, or A False Prophet, more of the apparent scandal around Apollonius emerges. Philostratus records a rumor that Apollonius had an affair with the mother of the sophist Alexander Peloplaton, implying that he was believed by some to have been the sophist's father (VS 570). Though in the VS too he denies the rumor, he is at least ready to give a little more detail in the later work. While he states that it is unbelievable ( $\dot{\alpha} \pi \hat{i} \theta \alpha v o v)$, his description of Alexander as having a similar godlike nature to Apollonius seems to leave the question open. Perhaps Philostratus felt able to speak more freely with his Severan former patrons no longer listening. ${ }^{30}$ There is a further whiff of scandal in Lucian's Alexander, or A False Prophet: Lucian

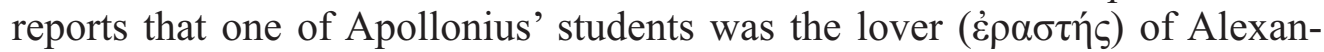
der of Abonouteichos (Alex. 5), adding that the association with Apollonius is enough to show what sort of man he was. All of this demonstrates at least that Philostratus had hostile traditions with which to contend when trying to establish Apollonius' celibacy.

Hippolytus is evoked on three occasions in the course of the $V A .{ }^{31}$ The youth Timasion, whom Apollonius and his party meet when traveling in Egypt, is directly compared to Hippolytus. Like Hippolytus, Timasion had an evil step-

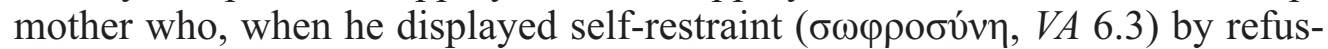
ing her advances, accused him of effeminacy and of preferring male lovers

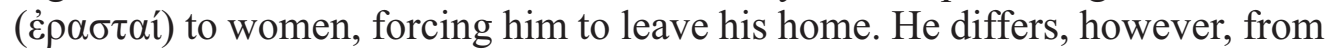
the Hippolytean model, in that he sacrifices daily to Aphrodite rather than scorning her, for which Apollonius praises him. Timasion, he says, is superior to Hippolytus in resisting illicit sex while honoring the divinity, since a mere aversion to one of the gods has nothing to do with real restraint ( $\sigma \omega \varphi \rho \circ \sigma u ́ v \eta, V A 6.3)$.

26. Francis 1995, 101 n. 68. On the "zero-sum game" in writers of the Second Sophistic, see Whitmarsh 2001b, 189 n. 37; on the same strategy as a "central device in Philostratus' extolling of Apollonius," see Whitmarsh 2001b, 233. On Apollonius' relationship to Pythagoras, see Flinterman 2009.

27. On disdain for the body and its influence in the Acts of Thomas, see Most 2005, 82-121 esp. 87-88. Chew $(2003,215-16)$ notes that while the Apocryphal Acts reject the moderation implied by sopphrosynē in favor of the more radical egkrateia, Christian martyr acts adopt instead the favored term in the novels: sōphrosynē.

28. For comparison of pagan and Christian asceticism, see Meredith 1976; P. Brown 1971. See also Francis 1995 on Apollonius as a "rehabilitated ascetic."

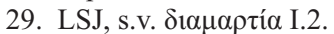

30. On the differences here between the treatments in the $V A$ and $V S$, see Bowie 1994, 192-93.

31. The story of Hippolytus is also treated at Imagines 2.4. The image there depicts the accident leading to the death of Hippolytus, a popular theme on sarcophagi as discussed above. The numerous echoes of Euripides in the ekphrasis demonstrate how detailed Philostratus' knowledge of the play was: see Schönberger 1968, 385-87. 
This stress on the struggle necessary for true self-control, which recurs in other scenes dealing with this theme, allows Philostratus to imply that Apollonius' own celibacy is heroic rather than simply a lack of desire or of virility. ${ }^{32}$

Another, very similar encounter recalling the myth of Hippolytus takes place toward the end of the $V A$, when Apollonius is in prison. Here, Apollonius meets a youth who has resisted the advances of Domitian, and is consequently incarcerated under threat of death, suffering too because of his chastity (VA 7.42). The comparison with Hippolytus is made once again by Apollonius, after the Arcadian's initial comment that "self-restraint" ( $\sigma \omega \varphi \rho о \sigma v ́ v \eta)$ is honored under contemporary law by capital punishment: "So too were the laws in Theseus' day,' he said, 'for Hippolytus' father himself killed Hippolytus for his selfrestraint [ $\sigma \omega \varphi \rho \circ \sigma u ́ v \eta] . "$ The similarity of the two episodes is further emphasized by the similar descriptions of the two youths' reactions to questioning about their stories. In the first scene Apollonius sees that Timasion blushes

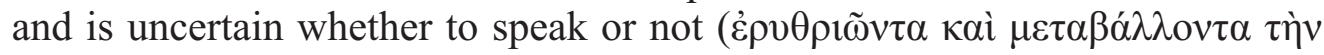

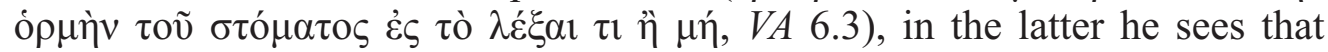

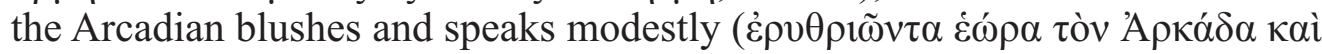

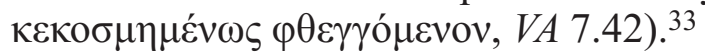

These two episodes present a symmetrical pair of Hippolyti, one resisting a male and one a female sexual predator. In light of these overt allusions to the myth of Hippolytus, two other details from the beginning of the $V A$ can take on a further meaning. Firstly, though on this occasion there is no direct reference to Hippolytus, Apollonius himself becomes as a youth an object of lust to a person in authority, the governor of Cilicia (VA 1.12). Of course, Apollonius refuses him in strong terms ("you're mad, you scum," $\mu \alpha i v \varepsilon \varepsilon . . . \tilde{\omega} \kappa \alpha ́ \theta \alpha \rho \mu \alpha$ ) but does not suffer at all for his resistance. Instead he predicts the death of the governor for his involvement in an anti-Roman plot. ${ }^{34}$ That this scene is part of the $V A$ 's series of references to Hippolytus may only become clear on a second reading with the other, clearer allusions to the same myth available to help make the connection. The similarity of the incident with the Cilician governor to the later Hippolytus stories invites comparison, too, between Apollonius and the same mythic model.

Earlier still, in the complex account of traditions concerning Apollonius' birth (1.5), the narrating voice had insisted on the location of his nativity in a meadow. An attentive reader might also recall this detail, in light of the overt evocations of Hippolytus later in the text, as a recollection of the imagery of Euripides' Hippolytus. ${ }^{35}$ In a famous and much discussed prayer to Artemis, Hip-

32. The central notion of self-control had by this time a long history. In Plato, this quality was to be developed early in education (Pl. Resp. 2-3). The word does not, however, bear a specifically sexual sense here, but rather refers to emotional control more generally. In this broad sense, the sōphrōn group of words continued to denote one of the cardinal, Platonic virtues. The chastity of the protagonists of ancient novels has been much discussed. See, among much else, Foucault 1994 and the response of Goldhill 1995; Konstan 1994; M. J. Anderson 1997.

33. Menippus also blushes in the lamia episode (VA 4.25) when questioned by Apollonius, another example of a youth corrected in sexual matters by a knowing elder. See also Philostr. Gym. 21-22.

34. Mumprecht $(1983,1029$ n. 40) comments that no such plot took place, explaining perhaps the vagueness of the date on which the governor is supposed to have been executed.

35. On this Euripidean meadow the fundamental study remains Segal 1965. 
polytus offers a garland, just picked from an untouched meadow (Eur. Hipp. 7387). ${ }^{36}$ Apollonius' mother, on the instruction of a dream, has gone out into a meadow to pick flowers, where she gives birth to the future philosopher. This is a complex scene, laden with mythic allusions for discussion in another context, but looking back from the later Hippolytus stories, or approaching the text as a re-reader, the allusion to the Hippolytus is clearly emphasized:

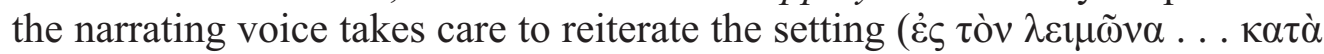

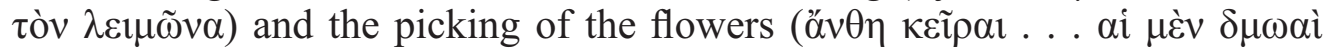

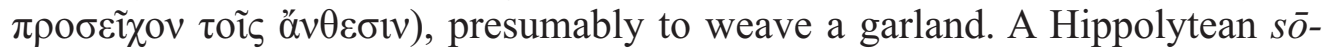
phrosyne is reflected back to Apollonius' birth itself.

The incident with the governor not long afterward implicitly rejects sex with men, just as Apollonius will explicitly reject sex with women in the next chapter. Along with the two later chapters in which Apollonius approves the pair of quasi-Hippolytean figures whom he meets, the episode with the governor allows Philostratus to depict the sage's celibacy as a heroic path of overcoming oneself and the aggressions of others. The attribution of two of the three incidents to other characters, featuring Apollonius in the role of approving elder, allows Philostratus to avoid the repetition of similar incidents occurring to his hero, which may have raised the suggestion that something in his appearance or character provoked such advances.

It is significant that of these three scenes, the two featuring a male aggressor both involve a Roman and a Greek, the Roman as predator and the Greek as nobly resisting prey. In both of these episodes, the motif of the rape of a noble youth as an act typical of tyrants is projected onto the Roman rulers, a pattern that Simon Goldhill observes in discussing a similar episode in Plutarch's Life of Cimon (1.2). There a Roman commander falls in love with a noble youth from Chaironeia named Damon, who responds violently to the Roman's attempt to seduce him, leading to the threat of Roman violence to the entire town, a threat averted by the intervention of another Roman, Lucullus. ${ }^{37}$ Plutarch's generally favorable attitude to Rome does not blind him to the possibility of Roman abuse of power, nor to the vulnerable position of Greece as a subject member of a larger empire. In this opening ancedote of the Cimon, as in the $V A$, this potential vulnerability is imagined in sexual terms.

How the VA's Arcadian youth came to be in Rome is also significant: he was sent by his father to learn Roman law rather than following the traditional Greek paideia of which Philostratus is himself a product. Jaap-Jan Flinterman reads this clash of educational systems as the point of this anecdote, ${ }^{38}$ and this certainly is one of Philostratus' major concerns here. Nonetheless, as Flinterman notes, this is not a straightforward condemnation of Roman power. Such a condemnation would be extraordinary coming from a sophist at the imperial court, and Philostratus is in general supportive of Rome. Though it is a Roman who is the source of the threat, the situation is also rectified by Rome, both in Philostratus and in Plutarch: by Lucullus in the Life of Cimon, by the

36. See Hunter 2009 on the evidence for ancient discussion of these verses in the scholia.

37. Goldhill 2002, 255.

38. Flinterman 1995, 228. 
unnamed emperor in Apollonius' case, and apparently by Domitian himself in the case of the Arcadian, since he seems to release the youth of his own accord. All three stories contain reassurance as well as anxiety, though the anxiety remains. Despite their reassuring closure, the appeal of these stories seems to be precisely that they touch on an area of unease. The evocation of Hippolytus, even when the story is rewritten to end happily, still carries tragic and menacing undertones.

In the $V A$, as in the novels, Hippolytus' story is not simply evoked as a precedent. Rather, it is made to interact in different ways with the narratives that frame it. Most strikingly, perhaps, the story is always rewritten with a happy ending, for the Hippolytus figure at least. The novels' protagonists, Cnemon, Apollonius, Timasion, and the nameless youth in prison do not come to any lasting harm, or at least not such a bloody end as their Euripidean forerunner. Apollonius is invulnerable in this respect as in others, and the other Hippolyti face only a period of exile or imprisonment. In this regard the specific treatment of latter-day Hippolyti resembles the tendency of the novels in treating the fortunes of the Liebespaar: though they suffer a period of dislocation they return after their adventures to the social stability from which they began. ${ }^{39}$

A happy ending for the VA's Hippolyti is also made possible by omitting from the story the offense of the original Hippolytus against Aphrodite. Timasion's daily sacrifices to Aphrodite win Apollonius' approval, implying that his own beliefs are the same, and consequently that his celibacy is not intended as an offense to the goddess (VA 6.3). ${ }^{40}$ Much as the novels of Xenophon and Chariton had corrected the initial offenses against sexuality of their protagonists, allowing for a positive resolution, the absence of the wrath of Aphrodite in the $V A$ as a driving force behind these stories allows for happier outcomes than in the Euripidean version. With the motif of offended divinity removed, Hippolytus can be used as a precedent in the definition of Apollonius' celibacy.

While the parallel with Hippolytus is drawn less explicitly in the case of Apollonius, he is in some respects the closest to the original Hippolytus among the VA's chaste young men. Unlike Timasion or the Arcadian boy, Apollonius' choice is overtly made out of religious/philosophical devotion, though it is a devotion to the ideal of Pythagoras rather than to Artemis. Furthermore, his celibacy alone is intended to be a permanent state, going beyond the resistance shown by Timasion and the Arcadian to inappropriate sexual advances.

\section{THE EUNUCH}

In addition to these Hippolytean stories, Apollonius' celibacy is defined by contrast with another character who appears briefly, the eunuch in Babylon (VA 1.33). Eunuchs, lust, and adultery form a popular topos, especially in "east-

39. On Bakhtin's idea of novelistic "adventure time" as an "extratemporal hiatus," see Bakhtin 1981, 89-90. For recent reassessments of Bakhtin's theories about the ancient novel, see the essays in Branham 2004, esp. Whitmarsh 2005 and Ballengee 2004; and Bemong et al. 2010. Perkins' (2001) comparison of the Greek novels and the Acts of the Martyrs is also revealing of the temporary nature of suffering in the novels.

40. This bears a close similarity to Apollonius' attitude to Dionysus: though he abstains from wine he is careful not to offend the deity (VA 2.7). 
ern" contexts; they are also combined, for instance, in the story of Stratonice and Combabos in Lucian's De Syria dea (19-27). ${ }^{41}$ As Bowie observes, "The theme of the eunuch in love seems to have been prominent in Iamblichus' 'Babyloniaca." " 42 In Lucian's Eunuch, the name of Bagoas ascribed to the apparent eunuch-philosopher evokes associations of oriental softness and luxury. ${ }^{43}$

This topos is put to use in the $V A$ in the process of defining, and indeed heroizing, Apollonius' celibacy. The episode begins with an example of the sage's precognition, when he discusses eunuchs with Damis in Babylon, asking whether castration has removed ability or desire. ${ }^{44}$ Damis is of the opinion that both are removed together, since if the member should be extinguished by which the body was driven mad, desire would no longer occur to anyone. ${ }^{45}$ Apollonius, however, disagrees, saying that the lusts of eunuchs, brought on through their eyes, ${ }^{46}$ remain hot and glowing, and that tomorrow they will see an example proving that even eunuchs are susceptible to desire. Even if it were possible to banish desire ( $\tau$ ò $\dot{\varepsilon} \rho \tilde{\alpha} v$ ) from the mind, this would not constitute self-control ( $\sigma \omega \varphi \rho о \sigma u ́ v \eta)$, which he defines instead as the ability to resist "this madness"( $\left.\tau \tilde{\eta} \varsigma \lambda v_{\tau} \tau \eta \varsigma \tau \alpha u ́ \tau \eta \varsigma, V A 1.33\right)$.

Of course, the encounter predicted by Apollonius takes place. While he and Damis are speaking with the king they are interrupted by a sudden commotion of women and eunuchs (VA 1.36). One of the eunuchs has been caught

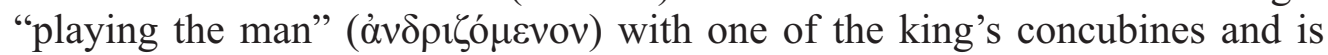
accordingly dragged by the hair before the king for judgment. The king puts the decision regarding the eunuch's fate to Apollonius, who comes to the "wise


alive to be endlessly tormented by his insatiable desires (VA 1.36).

This is an important incident in the construction of Apollonius' celibacy. Like Apollonius as a declared celibate, the eunuch appears to be outside the usual binaries of active/passive, male/female. Philostratus is careful, however, to make clear that Apollonius' abstention is a result of self-control ( $\sigma \omega \varphi \rho \circ \sigma u ́ v \eta)$, not of mere induced inability as in the case of the eunuch. More than just illustrating the Tyanean's superiority over another apparently asexual group, the incident

41. See Lightfoot's commentary: 2003, 384-86.

42. Bowie 1975, 1664-65. Regarding a narrative strategy somewhat similar to that employed by Philostratus here, see Morgan 1989 on the definition of Heliodorus' ideal of love by contrast with an opposite, perverse type of love. Cnemon's novella, Morgan $(1989,107)$ argues, "is a paradigm, of an inverse kind, that provides a scale against which the significance of the central plot can emerge." The eunuch functions similarly in the definition of Apollonius. Among the literature on eunuchs in antiquity in general, see Roller 1997, 542-55; Tougher 2002. Still useful on eunuchs and ideas of chastity is Nock 1925.

43. On Lucian's Eunuch in reference to Favorinus, details of whose biography are transferred to Bagoas, see Gleason 1995, 132-38.

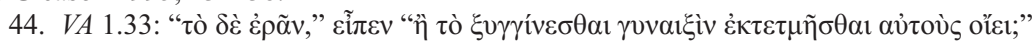

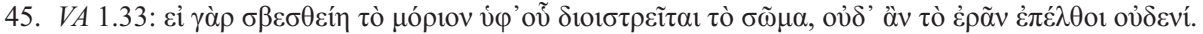

46. The importance of the eye and visuality in the theory of desire that Apollonius argues here (ö $\pi \varepsilon \rho$


Charicles in the Aethiopica. On this scene and the ideas that it contains, see Dickie 1991. The same connection of seeing and desiring (ó $\rho \tilde{\alpha} v, \dot{\varepsilon} \rho \tilde{\alpha} v)$ is found in Philostratus' Letters. The fifty-third letter, for instance, treats the

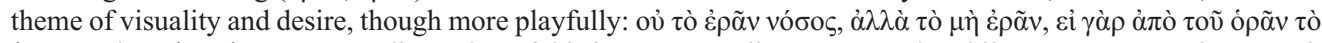

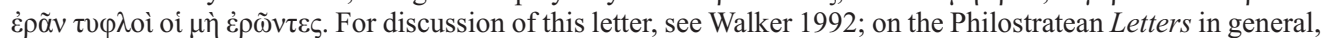
see Goldhill 2009; Hodkinson 2013; Rosenmeyer 2001, 322-38. In Achilles Tatius the connection of visuality and desire becomes a central interest of the text; see Morales 2005. 
serves, along with the Hippolytus stories discussed above, to define Apollonius' own celibacy. It is not an offense against Aphrodite (like that of Hippolytus), nor is it brought about simply by preventing the realization of desires. Where the eunuch inappropriately conflates and confuses masculine and feminine sexualities, Apollonius transcends them. ${ }^{47}$

Here too, moreover, Greek identity and sexual identity are entwined. The initial discussion between Apollonius and Damis begins with the sage wondering why the barbarians think that eunuchs are self-controlled ( $\sigma \omega \dot{\varphi} \rho \omega v)$. To the barbarian Damis, this seems commonsensical, and he replies that it is obvious to a child (VA 1.33). Apollonius, as the representative of Hellenic culture, is vindicated here as he is throughout the text. Self-control, it is implied, is part of a complete paideia, and as such is best understood by a Greek pepaideumenos. Apollonius' celibacy is superior both to the behavior of Romans who attempt to abuse their power and to the fake self-control of the eunuchs of the east.

The unfortunate Babylonian eunuch shares two of the three paradoxes of the life of the philosopher/sophist Favorinus, recounted in the Lives of the Sophists. ${ }^{48}$ Like Favorinus, he is a eunuch charged with adultery, ${ }^{49}$ and, like Favorinus, he comes into conflict with a king and lives. Favorinus' third paradox, that he was a Gaul who hellenized, that is, who both spoke Greek and lived in a Greek way, is not directly relevant to Philostratus' anonymous eunuch, but does raise the theme of Greeks and others, as does the incident in the $V A$. Where Favorinus, however, is concerned with flaunting his paradoxical ability to shift from one side of these distinctions to another, in particular to shift to the privileged side of each, the function of the $V A$ 's Babylonian eunuch is rather different. While here too the distinction between eunuch and potent male is played with, the Greek/barbarian boundary is policed and reinforced. The adulterous eunuch paradox provides an opportunity for Apollonius to demonstrate the superiority of Greek learning and self-control. Favorinus' paradoxes and the eunuch incident operate within the same system of oppositions and privilege the same terms within that system. Though there is certainly no necessity for readers to think of Favorinus when reading the passage in the $V A$, the structural similarities that can be seen between the perceptions of Favorinus and of the Babylonian eunuch do reveal a particular pattern of thought based around the topos of the adulterous eunuch.

\section{THE LAMIA}

Philostratus informs us that the most famous story about Apollonius prior to the writing of the $V A$ was that of his conflict with a lamia in Corinth (VA 4.25)..$^{50}$ Thanks to Keats' "Lamia" it can also claim to be the only remotely famous story about him in modern times. This episode too contributes to the construc-

47. Gleason $(1995,133$ n. 13) aptly quotes Eunuch 6 on the conflation of genders in the eunuch and the resultant monstrosity: "saying that the eunuch is neither man nor woman, but some composite and mixed and

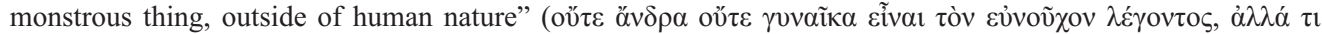

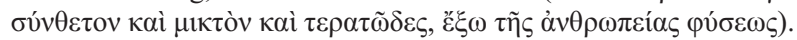

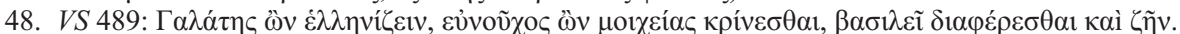

49. For the eunuch in love as a declamatory exercise, see Hermogenes (Rabe 1913, 59-60).

50. As G. Anderson $(2009,220-21)$ observes, the implication is that the story was already in circulation. 
tion of Apollonius' celibacy. While Apollonius is at Corinth, a new convert to Apollonius' philosophy named Menippus falls in love with a mysterious Phoenician woman and intends to marry her. Apollonius, with his greater insight, perceives that the supposed woman is in fact a lamia, who intends to devour the unfortunate Menippus after she has had sex with him.

Apollonius' encounter with the lamia is one of the relatively few occasions in which any female character appears. Other than this lamia/empousa, the narrative features another empousa encountered just past the Caucasus (VA 2.4); a woman whose son is possessed by the ghost of a soldier (3.38); a woman in a difficult labor who is assisted by the timely entrance of a hare (3.39); the halfblack, half-white woman just beyond the limits of Alexander's journey (3.3); Apollonius' mother $(1.4-5,5.15)$; the concubines in Babylon; ${ }^{51}$ the women harassed by a satyr (6.27); ${ }^{52}$ Timasion's Phaedra-like stepmother (6.3); and the Cilician girl bedded by her stepfather, whom Apollonius meets in his youth at the temple of Asclepius (1.10). Most of these women are defined solely as sexual beings, whether as the object of another's lust, such as the Cilician girl and the king's wives; as maternal figures, such as Apollonius' mother and the woman in a difficult labor among the Brahmans; or as sexual predators, such as Timasion's stepmother and the lamia. The only female characters who are not defined in sexual terms are monstrous: the black-and-white woman and the first empousa.

The Corinthian empousa or lamia is the most developed of the text's female traps, ${ }^{53}$ combining several features found in the other female characters who only briefly appear. Like all of the text's predatory and monstrous females, she occupies a liminal position, as an outsider (a Phoenician) in Corinth. Similarly, the black-and-white woman appears at the border of the unknown lands beyond the limits of Alexander's journey; the first empousa appears when the travelers have just entered India, passing the boundary formed by the "Caucasus"; and Timasion's persecutor is the inevitably evil stepmother, a liminal role in the household, neither truly a mother nor an outsider. ${ }^{54}$

An uncomfortable mixture of internal and external is raised both by the identity assumed by the lamia and by the city in which she hunts her prey. As Françoise Briquel-Chatonnet notes, Phoenicians in the novels are both thoroughly hellenized and associated with a number of stereotypical "foreign" traits: luxury, debauchery, piracy, and barbarous ceremonies. ${ }^{55}$ In view of this perception of Phoenicians, the choice of identity by the lamia is surely an appropriate one. Briquel-Chatonnet speculates that the practice of sacred prostitution, producing the Greek notion of Phoenician debauchery, may underlie the lamia's choice of mask. ${ }^{56}$ The connotation of luxury is equally appropriate,

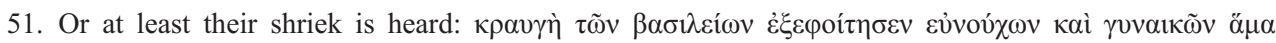
(VA 1.36).

52. Like the wives of the king, these women are also heard from outside the scene: ßoñऽ $\dot{\alpha} \theta \rho \alpha_{\alpha} \varsigma \tau \tilde{\omega} v \dot{\varepsilon} v \tau \tilde{\eta}$



53. On traditions regarding lamia and empousa in general, see Halm-Tisserant 1989; West 1991; C. G. Brown 1991.

54. See Watson 1995

55. Briquel-Chatonnet 1992.

56. Briquel-Chatonnet 1992, 102. 
especially as the lamia is regarded as tempting Menippus away from the philosophical life that he had formerly led. The Greek belief in the practice of human sacrifice among the Phoenicians, whether justified or not, is well known, ${ }^{57}$ and it too may be evoked by the murder of Menippus planned by the (illusory) Phoenician woman.

While these stereotypes are appropriate to the lamia's monstrous true nature, her deceptive facade is matched by the Hellenic appearance of the Phoenicians. The Phoenician merchant in Philostratus' Heroicus cannot be distinguished from an Ionian in his appearance, and his knowledge of and interest in Hellenic tradition are evidently extensive. ${ }^{58} \mathrm{He}$ is a non-Greek who could certainly pass himself off as Greek if he so chose. The facade of the lamia is more sinister. While she is not even a human being, she is concealed behind a Phoenician mask, which itself can easily appear to be that of a Greek. One mask that announces itself as such (Phoenician rather than Greek) conceals a second layer of deception.

The cultural identity of Corinth is similarly ambiguous despite its position, as Philostratus notes, "in the middle of Greece" ( $\kappa \alpha \theta$ ' $E \lambda \lambda \alpha \dot{\alpha} \delta \alpha \mu \varepsilon \dot{\sigma} \sigma \nu, V A 4.25)$. As Luca Graverini observes, Corinth had immense resonance in both Greek and Latin culture; the rebuilt city was a Roman one, which over time had become thoroughly hellenized, "a perennial symbol of the relationship between Greece and Rome." 59 The setting of the story here, whether it was part of the earlier traditions surrounding Apollonius or is Philostratus' addition, evokes these associations. ${ }^{60}$ The cultural ambiguity of the lamia is matched by the setting in which she chooses to operate. The other associations of Corinthits wealth, corruption, and immorality - are also shared by the empousa. ${ }^{61}$ All of these qualities contrast sharply with those with which Philostratus credits Apollonius: his true Hellenism, his celibacy and indifference to wealth, his truthfulness.

In the account of the Corinthian lamia, Philostratus emphasizes visuality and appearance. It is by her apparent beauty that Menippus is swayed, and the lavish feast turns out to be merely appearance. The first empousa is also characterized as deceptive and illusory, changing herself from one form to another,

57. Briquel-Chatonnet 1992, 102-3. It may also be worth noting that the better-known Menippus was supposedly of Phoenician descent (Diog. Laert. 6.99).

58. Ionic appearance: Her. 1.1-1.6. Regarding the choice of a Phoenician in the Heroicus, see Bradshaw Aitken 2004. The remainder of the dialogue demonstrates his Hellenic interests. On the Hellenism of the Phoenicians generally, see Briquel-Chatonnet 1992, 99-100.

59. Graverini 2002. On Favorinus' speech to the Corinthians regarding his statue, and his play with the split identity of the city, see Whitmarsh 2001a.

60. The ending that Philostratus gives to this episode seems to indicate that the Corinthian setting was already established. While he expects that readers will have heard "that [Apollonius] once captured a lamia in

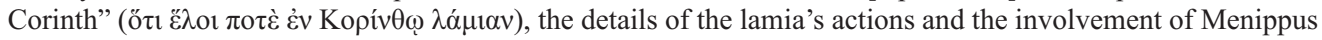
are introduced on the authority of Damis. This seems a clear indication of what is original and what is elaborated by Philostratus himself, as Bowie $(1994,191)$ observes.

61. Graverini 2002, 59. Mason $(1971,162)$ compares with Philostratus' narrative the sexual adventures and transformation of Lucius at Corinth in Apuleius' Golden Ass: "Behind both lies the same mixture of perverse and uncontrolled sexuality and form-changing magic, and Philostratus, like Apuleius, chose to associate these qualities with Corinth." He also notes that Corinth is represented "as a city of sexual perversion and murder" in the story of Apollonius' encounter with the parricide Bassus, briefly recounted at VA 4.26 and in Apollonius' Letters 36-37 (p. 163). Further on Apuleius' choice of Corinth, see Jones 2014. 
as did her literary ancestor in Aristophanes' Frogs (VA 2.4; Ar. Ran. 285-303). Philostratus' treatment of the first empousa is rather abbreviated, not even specifying which forms she took. ${ }^{62}$ This may be in part because he is saving his energies for the second, more developed empousa story, and also because the first episode is just one in a collection of wonders on the journey to India. It is also possible that he was deliberately avoiding too close an association with the Frogs, as it would be very easy to call the comedy to mind given the similarity of situation (master and follower enter a strange land and meet an empousa). The lamia of Corinth, too, is not really a woman, but just an apparition $(\varphi \alpha ́ \sigma \mu \alpha)$, and the wedding feast that she creates is also illusory. This tendency to illusion and metamorphosis is a supernatural development of the common characterization of women as deceptive, but in the context of the $V A$ it is also a sinister variation on the Protean character of Apollonius. Like the lamia, Apollonius too is physically attractive and Protean. ${ }^{63}$ In this light, the empousai appear as distorted reflections of the hero who overcomes them. Menippus' devotion to one attractive, Protean figure, Apollonius, is threatened by his devotion to another, at least until she is overcome. ${ }^{64}$

Both empousai are defeated by words alone, the first when Apollonius shouts abuse at her (which Philostratus refrains from quoting). Similarly, he defeats the Corinthian lamia by out-talking her and forcing her into a confession. The hero, with his supreme control of language, forces these threatening female figures out of the text entirely, and from a text from which females are largely banished already. Both text and hero enact an expulsion of women from discourse by means of discourse. As Bowie observes, the negative view of erōs in the $V A$ is unlike that found in Philostratus' other works. It is required for the depiction of Apollonius' asceticism and celibacy, and is quite different from the more positive depiction found in the other works of the corpus. ${ }^{65}$

This banishment by language is applied not only to female monsters, but rather to lecherous spirits in general. The two empousai in India and Greece are balanced by two libidinous, male ghosts, one in India (VA 3.38) and another in Egypt/Ethiopia (VA 6.27). These two incidents, it may be added, form part of another of the text's symmetrical arrangements, the system of parallels between India and Egypt/Ethiopia. Here, as in the Bride of Corinth, the narrative concerns the liberation of a person or group from the unwanted lust of a spirit, by an anonymous sage ( $\tau$ vò $\varsigma \tau \tilde{\omega} v \sigma o \varphi \tilde{\omega} v)$ in the first episode and by Apollonius in the second. However, while monstrous figures constitute a proportionally large part of the overall female cast, the male monsters represent a relatively small part of the total number of male characters.

In the first incident, an Indian boy has become possessed by the ghost of a soldier whose wife had remarried only three days after his death. The soldier

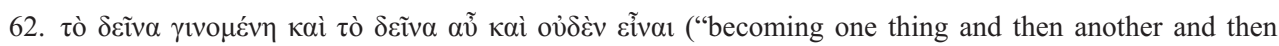
nothing at all," VA 2.4).

63. On Apollonius' physical attractiveness: VA 1.7. The stories of Apollonius' birth, like those of his death, are decidedly ambivalent about his nature, but the explanation of his origins told at greatest length proclaims him an incarnation of Proteus (VA 1.4).

64. On this scene and its relationship to the education of Menippus, see Miles and Demoen 2009.

65. Bowie 1994, 192-93. 
had converted in disgust from women to boys as his erotic objects of choice, and focused on one particular boy, whose mother comes to the Brahmans for help. Spiritual possession appears here as a substitute for sexual possession. The boy himself is not present because the spirit has threatened to kill him if his mother tries to get help (VA 3.38). In the later incident, Apollonius and his disciples stop overnight in a village that turns out to be troubled by the ghost of a satyr who is pursuing the local women and has already killed two of his particular favorites ( $V A$ 6.27). As Bowie observes, "[a]gain sexual desire involves a desire to kill," a recurrent connection in the $V A .{ }^{66}$

The responses to these problems are both based in an ideal of paideia. The soldier's ghost is banished by words just as the lamia will be, but in this instance by means of a written text, a threatening letter which the Brahman sage produces. Furthermore, the mother complains that the possessing spirit will not allow her son to go to the house of the teacher (VA 3.38). Just as Menippus is later in danger of being seduced away from philosophy by the lamia, the Indian boy in this episode is driven away from his education by the lustful spirit. The approach taken by the Brahman resembles the method for hunting dragons mentioned some chapters earlier, charming them to sleep with a purple cloth on which golden letters have been sewn ( $V A$ 3.8). Insofar as it depends on language, it also resembles Apollonius' responses to the two lamiai.

Apollonius' actions later in dealing with the ghost of a satyr may seem to depart from the pattern of dealing with lecherous spirits through textual or verbal means. Instead, he overcomes this apparition by imitating Midas, who captured a satyr by making it drunk. Once the satyr has drunk a trough full of wine and fallen asleep, Apollonius forbids the villagers to strike it or to abuse it $(\lambda o 1 \delta o \rho \varepsilon \tilde{\sigma} \sigma \theta \alpha)$. The banishment by abusive language that he used against the

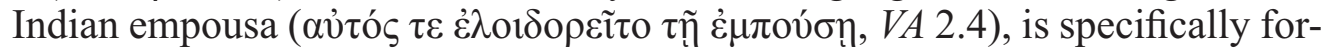
bidden here. Though Apollonius does not on this occasion solve the problem by language alone, he does derive his knowledge of what to do from Greek tradition, from his mastery of Hellenic paideia. As was the case with the Corinthian lamia, the satyr offers a counterimage to Apollonius: like other satyrs it is addicted to sex and wine, some of the indulgences that are most firmly rejected by Apollonius.

\section{CONCLUSION}

Some patterns appear from these four connected incidents (the lamia, the Indian empousa, the soldier's ghost, and the ghost of a satyr). In three of the four cases the problem is overcome by language, in the fourth by knowledge of Greek myth. While both of the empousai are dismissed in this way, only the male spirit that is preying on a male victim is treated similarly. The satyr, despite having killed two women, is merely restrained from his "senselessness"

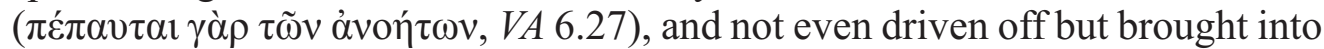
peaceful relations with the villagers on Apollonius' advice.

66. Bowie 1994, 192. 
These stories of lustful spirits, along with those of the Hippolyti and the eunuch, serve to develop Apollonius' characterization as a celibate ascetic. The overwhelmingly negative view of sexual desire that is presented casts the hero's abstention in a positive light, and his successes in dealing with these various incidents show that he can not only overcome the incursions of desire into his own mind, but can also extend his powers into the affairs of others and into the supernatural. Apollonius' victories over lustful spirits, along with his careful distinction from the eunuch and conditional assimilation to the figure of Hippolytus, establish his celibacy as heroic, rather than simply a lack of virility.

University of Tasmania

\section{LITERATURE CITED}

Abraham, Roshan. 2014. The Geography of Culture in Philostratus' Life of Apollonius of Tyana, CJ 109: 465-80.

Alpers, Klaus. 1996. Zwischen Athen, Abdera und Samos: Fragmente eines unbekannten Romans auf der Zeit der Zweiten Sophistik. In Kainotomia: Die Erneuerung der griechischen Tradition, ed. Margarethe Billerbeck and Jacques Schamp, 19-55. Freiburg.

Anderson, Graham. 1986. Philostratus: Biography and Belles Lettres in the Third Century AD. London.

1993. The Second Sophistic: A Cultural Phenomenon in the Roman Empire. London. 1994. Sage, Saint and Sophist: Holy Men and Their Associates in the Early Roman Empire. London.

- 1996. Philostratus on Apollonius of Tyana: The Unpredictable on the Unfathomable. In The Novel in the Ancient World, ed. Gareth Schmeling, 614-15. Leiden.

- 2009. Folklore Versus Fakelore: Some Problems in the Life of Apollonius. In Demoen and Praet 2009, 211-23.

Anderson, Michael J. 1997. The Sôphrosune of Persinna and the Romantic Strategy of Heliodorus' Aethiopica. CP 92: 303-32.

Bakhtin, Mikhail Mikhailovich. 1981. The Dialogic Imagination. Trans. Caryl Emerson and Michael Holquist. Austin.

Ballengee, Jennifer R. 2004. Below the Belt: Looking into the Matter of Adventure-Time. In The Bakhtin Circle and Ancient Narrative, ed. Robert Bracht Branham, 130-63, Ancient Narrative Supp. 4. Eelde.

Bartsch, Shadi. 1989. Decoding the Ancient Novel: The Reader and the Role of Description in Heliodorus and Achilles Tatius. Princeton, N.J.

Bemong, Nele, Pieter Borghart, Michel De Dobbeleer, Kristoffel Demoen, Koen De Temmerman, and Bart Keunen, eds. Bakthin's Theory of the Literary Chronotope: Reflections, Applications, Perspectives. Ghent.

Billault, Alain. 1991. Les formes romanesques de l'heroïsation dans la Vie d'Apollonios de Tyane de Philostrate. BAGB 1991: 267-74.

. 2000. L'Univers de Philostrate. Brussels.

2009. Les choix narratifs de Philostrate dans la Vie d'Apollonios de Tyane. In Demoen and Praet 2009, 3-19.

Bowie, Ewen L. 1975. Apollonius of Tyana: Tradition and Reality. ANRW 2.16.2: 1652-99.

. 1994. Philostratus: Writer of Fiction. In Greek Fiction: The Greek Novel in Context, ed. John R. Morgan and Richard Stoneman, 181-238. London. 
Bowie, Ewen L., and Jaś Elsner, eds. 2009. Philostratus. Cambridge.

Bradshaw Aitken, Ellen. 2004. Why a Phoenician? A Proposal for the Historical Occasion for the Heroikos. In Philostratus' "Heroikos": Religion and Cultural Identity in the Third Century C.E., ed. Ellen Bradshaw Aitken and Jennifer K. Berenson Maclean, 267-84. Atlanta.

Bremmer, Jan. 2013. Myth in the Novel: Some Observations. In Intende, Lector-Echoes of Myth, Religion and Ritual in the Ancient Novel, ed. Marília P. Futre Pinheiro, Anton Bierl, and Roger Beck, 17-23. Berlin.

Briquel-Chatonnet, Françoise. 1992. L'image des Phéniciens dans les romans grecs. In Le monde du roman grec, ed. Marie-Françoise Baslez, Philippe Hoffmann, and Monique Trédé, 99-107. Paris.

Brown, Christopher G. 1991. Empousa, Dionysus and the Mysteries: Aristophanes, Frogs $285 \mathrm{ff}$. CQ 41: 41-50.

Brown, Peter. 1971. The Rise and Function of the Holy Man in Late Antiquity. JRS 61: 80-101.

Burkert, Walter. 1972. Lore and Science in Ancient Pythagoreanism. Trans. Edwin L. Minar Jr. Cambridge, Mass.

Chew, Kathryn. 2003. The Chaste and the Chased: $\Sigma \Omega \Phi P O \Sigma Y N H$, Female Martyrs and Novelistic Heroines. SyllClass 14: 205-22.

Conybeare, F. C., trans. 1912. Philostratus: "Life of Apollonius of Tyana." Boston.

Cueva, Edmund P. 2004. The Myths of Fiction: Studies in the Canonical Greek Novels. Ann Arbor, Mich.

Demoen, Kristoffel, and Danny Praet, eds. 2009. Theios Sophistes: Essays on Flavius Philostratus' "Vita Apollonii." Leiden.

De Temmerman, Koen. 2014. Crafting Characters: Heroes and Heroines in the Ancient Greek Novel. Oxford.

De Temmerman, Koen, and Kristoffel Demoen. 2011. Less than Ideal Paradigms in the Greek Novel. In Echoing Narratives: Studies of Intertextuality in Greek and Roman Prose Fiction, ed. Konstantin Doulamis, 1-20. Groningen.

Dickie, Matthew W. 1991. Heliodorus and Plutarch on the Evil Eye. CP 86: 17-29.

Dijk, Gert-Jan Van. 2009. The Odyssey of Apollonius: An Intertextual Paradigm. In Bowie and Elsner 2009, 176-204.

Diggle, James, ed. 1984. Euripidis fabulae. Vol. 1. Oxford.

Elsner, Jaś. 1997. Hagiographic Geography: Travel and Allegory in the Life of Apollonius of Tyana. JHS 117: 22-37.

— 2001. Describing Self in the Language of Other: Pseudo (?) Lucian at the Temple of Hierapolis. In Being Greek under Rome: Cultural Identity, the Second Sophistic and the Development of Empire, ed. Simon Goldhill, 123-53. Cambridge.

Flinterman, Jaap-Jan. 1995. Power, Paideia and Pythagoreanism: Greek Identity, Conceptions of the Relationship between Philosophers and Monarchs and Political Ideas in Philostratus' "Life of Apollonius." Amsterdam.

- 2009. "The Ancestor of My Wisdom": Pythagoras and Pythagoreanism in the Life of Apollonius. In Bowie and Elsner 2009, 155-75.

Foucault, Michel. 1984. Histoire de la sexualité. Vol. 3, Le souci de soi. Paris.

Francis, James A. 1995. Subversive Virtue: Asceticism and Authority in the Second Century Pagan World. University Park, Pa.

1998. Truthful Fiction: New Questions to Old Answers on Philostratus' Life of Apollonius. AJP 119: 419-42.

Gleason, Maud W. 1995. Making Men: Sophists and Self-Presentation in Ancient Rome. Princeton, N.J.

Goldhill, Simon. 1995. Foucault's Virginity: Ancient Erotic Fiction and the History of Sexuality. Cambridge. 2002. Who Needs Greek? Contests in the Cultural History of Hellenism. Cambridge. 
2009. Constructing Identity in Philostratus' Love Letters. In Bowie and Elsner 2009, 287-308.

Graverini, Luca. 2002. Corinth, Rome, and Africa: A Cultural Background for the Tale of the Ass. In Space in the Ancient Novel, ed. Michael Paschalis and Stavros Frangoulidis, 58-66, Ancient Narrative Supp. 1. Eelde.

Grimal, Pierre, trans. 1958. Romans grecs et latins. Paris.

Hägg, Tomas. 2012. The Art of Biography in Antiquity. Cambridge.

Halm-Tisserant, Monique. 1989. Folklore et superstition en Grèce classique: Lamia torturée? Kernos 2: 67-82.

Hodkinson, Owen. 2013. Epistolography. In A Companion to Greek and Roman Sexualities, ed. Thomas K. Hubbard, 463-78. Malden, Mass.

Hunter, Richard. 1997. History and Historicity in the Romance of Chariton. ANRW 2.34.2: 1055-86.

- 2009. The Garland of Hippolytus. Trends in Classics 1: 18-35.

Jones, Christopher P. 1974. The Reliability of Philostratus. In Approaches to the Second Sophistic, ed. Glen W. Bowersock, 11-16. University Park, Pa. . 2001. Apollonius of Tyana's Passage to India. GRBS 42: 185-99. , trans. 2005. Philostratus: "Life of Apollonius of Tyana." Cambridge, Mass. 2014. Apuleius, Corinth, and Two Epigrams from Nemea. ZPE 192: 115-20.

Kingsley, Peter. 1994. From Pythagoras to the Turba Philosophorum: Egypt and Pythagorean Tradition. JWarb 57: 1-13.

Konstan, David. 1994. Sexual Symmetry: Love in the Ancient Novel and Related Genres. Princeton, N.J.

Koskenniemi, Errki. 1991. Der philostrateische Apollonius. Commentationes Humanarum Litterarum 94. Helsinki.

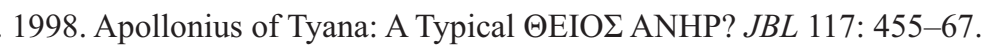

Lightfoot, Jane L. 2003. Lucian: "On the Syrian Goddess.” Oxford.

Linant de Bellefonds, Pascale. 1990. Hippolytus I. LIMC 5.1.445-64, 5.2.316-27. 1994. Phaedra. LIMC 7.1.356-59, 7.2.314-16.

Maclean, Jennifer K. Berenson. 2004. The aivos of the Heroikos and the Unfolding Transformation of the Phoenician Merchant. In Philostratus " Heroikos": Religion and Cultural Identity in the Third Century C.E., ed. Ellen Bradshaw Aitken and Jennifer K. Berenson Maclean, 251-65. Atlanta.

Mason, H. J. 1971. Lucius at Corinth. Phoenix 25: 160-65.

Meredith, Anthony. 1976. Asceticism—Christian and Greek. JThS, n.s., 27: 313-32.

Meyer, Eduard. 1917. Apollonios von Tyana und die Biographie des Philostratos. Hermes 52: 371-424.

Miles, Graeme. 2009. Reforming the Eyes: Interpreters and Interpretation in the Vita Apollonii. In Demoen and Praet 2009, 129-60.

Miles, Graeme, and Kristoffel Demoen. 2009. In Praise of the Fable: The Philostratean Aesop. Hermes 137: 28-44.

Morales, Helen L. 2005. Vision and Narrative in Achilles Tatius' "Leucippe and Clitophon." Cambridge.

Morgan, John R. 1989. The Story of Cnemon in Heliodoros' Aithiopika. JHS 109: 99-113. 2009. The Emesan Connection: Philostratus and Heliodorus. In Demoen and Praet 2009, 263-81.

Most, Glenn W. 2005. Doubting Thomas. Cambridge, Mass.

Mumprecht, Vroni. 1983. Das Leben von Apollonios von Tyana. Berlin.

Nauck, August, and Bruno Snell. 1964. Tragicorum graecorum fragmenta. Hildesheim.

Nock, A. D. 1925. Eunuchs in Ancient Religion. ArchRW 23: 25-33.

O’Meara, Dominic J. 1990. Pythagoras Revived: Mathematics and Philosophy in Late Antiquity. Oxford. 
Perkins, Judith. 2001. Space, Place, Voice in the Acts of the Martyrs and the Greek Romance. In Mimesis and Intertextuality in Antiquity and Christianity, ed. Dennis R. MacDonald. 117-37. Harrisburg.

Praet, Danny, Kristoffel Demoen, and Wannes Gyselinck. 2014. Domitian and Pentheus, Apollonius and Dionysos; Echoes of Homer and of Euripides' Bacchae in Philostratus' Vita Apollonii. Latomus 70: 1058-67.

Rabe, Hugo, ed. 1913. Hermogenis opera. Leipzig.

Radt, Stefan. 1977. Tragicorum graecorum fragmenta. Vol. 4, Sophocles. Göttingen.

Rattenbury, R. M., and T. W. Lumb. 1994. Héliodore: “Les Éthiopiques." Vol. 1. Paris.

Roller, Lynn E. 1997. The Ideology of the Eunuch Priest. Gender and History 9: 542-55.

Rosenmeyer, Patricia A. 2001. Ancient Epistolary Fictions. Cambridge.

Schirren, Thomas. 2005. Philosophos Bios: Die antike Philosophen-biographie als symbolische Form; Studien zur "Vita Apollonii" des Philostrat. Heidelberg.

Schönberger, Otto. 1968. Philostratos: "Die Bilder.” Munich.

Schwartz, Eduard. 1891. Scholia in Euripidem. Vol. 2. Berlin.

Scourfield, J. H. D. 2010. Chaereas, Hippolytus, Theseus: Tragic Echoes, Tragic Potential in Chariton. Phoenix 64: 291-313.

Segal, Charles P. 1965. The Tragedy of the Hippolytus: The Waters of Ocean and the Untouched Meadow. HSCP 70: 117-69.

Tougher, Shaun, ed. 2002. Eunuchs in Antiquity and Beyond. London.

Walker, Andrew. 1992. Eros and the Eye in the Love-letters of Philostratus. PCPS 38: 132-49.

Watson, Patricia A. 1995. Ancient Stepmothers: Myth, Misogyny and Reality. Leiden.

West, David R. 1991. Gello and Lamia: Two Hellenic Daemons of Semitic Origin. UgaritForschungen 22: 351-68.

Whitmarsh, Tim. 2001a. Greece Is the World: Exile and Identity in the Second Sophistic. In Being Greek under Rome: Cultural Identity, the Second Sophistic and the Development of Empire, ed. Simon Goldhill, 269-305. Cambridge.

. 2001b. Greek Literature and the Roman Empire: The Politics of Imitation. Oxford.

2004. Dialogues in Love: Bakhtin and His Critics on the Greek Novel. In The Bakhtin Circle and Ancient Narrative, ed. Robert Bracht Branham, 107-29, Ancient Narrative Supp. 3. Eelde.

Winkler, John. 1982. The Mendacity of Calasiris and the Narrative Strategy of Heliodorus' Aithiopika. YCS 27: 93-158.

Zanker, Paul, and Björn C. Ewald. 2012. Living with Myths: The Imagery of Roman Sacrophagi. Trans. Julia Slater. Oxford.

Zhmud, Leonid. 2012. Pythagoras and the Early Pythagoreans. Trans. Kevin Windle and Rosh Ireland. Oxford. 